EPRA International Journal of Economic and Business Review-Peer Reviewed Journal

Volume - 9, Issue - 11, November 2021 | e-ISSN: 2347 - 9671| p- ISSN: 2349 - 0187

\title{
AN ANALYSIS OF FACTORS AFFECTING NON-PERFORMING ASSETS IN INDIAN BANKING SECTOR
}

\author{
Bhabani Mishra ${ }^{1}$ \\ ${ }^{1}$ PhD Research Scholar, Dept. of Economics, Sambalpur University, Jyoti Vihar, Burla, Odisha, India
}

\begin{abstract}
DOI No: 10.36713/epra8991

Article DOI: https://doi.org/10.36713/epra8991

Deterioration of asset quality destabilizes the financial system by adversely affecting the efficiency, profitability, solvency and liquidity of the banking sector. Both macroeconomic and bank specific factors should be analysed properly to know their strength and direction of impact on the bad assets to have effective NPA resolution mechanism. Unemployment Rate Inflation, Economic Growth, Export rate, Exchange rate, Fiscal Deficit ratio are the macroeconomic indicators and Return on Assets, Credit Deposit ratio, Net Interest Margin are the bank specific factor that are taken from 2003-04 to 2019-20 to explain the variability in Non-performing assets of Public sector and Private sector banks. Fixed effect estimation with robust clustered standard error is used for the panel data regression. Paper found that except unemployment rate all other variables have significant impact on bad assets. Bank specific factor have strong negative impact on the dependent variables. Only exchange rate affects the non-performing loans positively but other macroeconomic variables are negatively associated.
\end{abstract}

KEYWORDS: Non-Performing Assets, Macroeconomic indicators, bank specific factors, Fixed effect

\section{INTRODUCTION}

As banking institutions plays a critical role in an economy so it is necessary to recognise the problems that disturb the performance of these banking institutions (Kaur and Kumar, 2018). The indecisive and sluggish policy practice of bank can cause financial instability and insecurity that eventually lead to downswing in the entire economy. Piling up bad assets in the loan portfolio is one of the most significant reasons for the bank failure. Deterioration of asset quality destabilize the financial system by constraining capital flow, harming the efficiency, profitability, solvency and liquidity of the banks. Timely detection of impaired loans and effective resolution or minimisation of this financial pollution is quite necessary to avoid major crises.
In Indian subcontinent, however, incidence of loan default is attributed mainly to lack of effective monitoring and supervision on the part of banks, lack of effective lenders' recourse, weaknesses of legal infrastructure and lack of effective debt recovery strategies (Bardhan, Sharma and Mukherjee, 2019).

Rest of the paper constitutes of data and methodology in the second section. Third section explains the result and discussion. Fourth section concludes the paper.

\subsection{Review of Literature}

Earlier studies have mentioned two sets of factors that explain the variability in the bad assets over time. The macroeconomic variables such as 
economic growth, unemployment, Inflation, exchange rate, export ratio affects both lending and borrowing processes. During boom, banks lend to more profitable businesses which have least chance of defaults. So, gradually they can manage their assets quality. Borrowers also can able to repay their earlier debt during economic growth and eventually reduce the size of non-performing assets (Waqas et al, 2017; Mazreku et al., 2018; Szarowska, 2018; Kuzucu and Kuzucu, 2019).

GDP growth have negative and significant impact on bad assets as suggested by Swamy (2012); Prasanna, Thenmozhi, Rana. (2014); Ghosh (2015); Roy (2014); Kanayake and Azeez (2015); Reddy (2015); Patra and Padhi (2016); Rajha (2016); Kaur and Kumar (2018); Mohanty, Das and Kumar. (2019); Zheng, Bhowmik \& Sarker (2019) in their articles. But some literatures such as Kadanda and Raj (2018) and Thomas and Thakur (2021) had found the past GDP growth had strong positive impact on NPAs.

Inflation (Ghosh, 2015 and Bhattarai, 2018) and recession adversely affect their repayment capacity, thus lead to more stressed assets having positive impact on it. The positive association of unemployment with NPAs is proved by Prasanna, Thenmozhi, Rana (2014); Patra and Padhi (2016); Kaur and Kumar (2018) in the context of Indian Banks and other paper such as Klein (2013); Ghosh (2015); Waqas et al. (2017) ; Mazreku et al. (2018) ; Szarowska (2018) ; in the context of Foreign countries.

Growth in exports has spread effect to its allied sectors which could generate more revenue and employment. So, increase export indirectly reduces the size of stressed assets of banking sector (Ahmad and Bashir, 2013). Rupees exchange rate against US dollar is also affecting the non performing assets of banks (Prasanna, Thenmozhi, Rana., 2014) and Klein, 2013). Whereas, Kaur and Kurmar (2018) had shown negative impact of exchange rate on NPAs. Patra and Padhi (2016) and Kumar et al. (2018) also had found exchange rate as insignificant to explain variability in NPA.

Expansionary fiscal policy as reflected in higher fiscal deficit ratio lead to spending more by the Government as compared to the available resources. When additional fund is raised through public borrowings, the shortages of capital leads to lower productivity and Profitability of private sectors which constrain the debt repayment capacity eventually ending up with huge stressed assets (Patra and Padhi, 2016 and Mohanty, Das and Kumar. 2019)

The second one, bank specific variables; such as Net Interest Margin, Return on Assets, Credit deposit Ratio can explain more efficiently the changes in impaired loans across banks as described in earlier studies.Net Interest Margin is also called as spread which is negatively associated with NPAs as per Pearson correlation in this paper (Dhar and Bakshi,
2015 and Sopan and Dutta, 2018). More interest earned by banks can help them to enhance their asset quality. Bank can also avoid more risky projects that have higher chances of loan defaults.

Many empirical studies have found that profitability in terms of ROA had significant negative impact on NPAs (Prasanna, Thenmozhi, Rana. (2014); Ghosh, 2015; Reddy, 2015; Kanayake and Azeez, 2015; Patra and Padhi, 2016; Bhattarai, 2018; Kaur and Kumar, 2018; Ramesh, 2019). Earlier paper such as Swamy (2012); Mohanty, Das and Kumar. (2019) and Ramesh (2019) had suggested that higher credit deposit ratio lead to decline in NPA sizes reflecting and negative association between them.

\subsection{Objectives}

1) To analyse the impact of bank specific variables on NNPA of Public sector and Private sector banks from 2004 to 2020.

2) To analyse the impact of macroeconomic factors on NNPA of Public sector and Private sector banks from 2004 to 2020.

\subsection{Hypotheses}

H0: There is no significant impact of bank specific determinants on Non-performing advances for selected Banks in India.

$\mathrm{H} 1$ : There is no significant impact of bank specific determinants on Non-performing advances for selected Banks in India.

H0: There is no significant impact of macroeconomic determinants on Non-performing advances for selected Banks in India.

$\mathrm{H} 1$ : There is no significant impact of macroeconomic determinants on Non-performing advances for selected Banks in India.

\section{DATA AND METHODOLOGY}

Indian banking system is confounded by deteriorating asset quality and a momentous rise in non-performing assets (NPAs) which is a cause of major concern for the sector, the regulators and other stakeholders (Thomas and Thakur, 2021). Effective NPA resolution mechanism cannot get succeed if deep root cause of it are not analysed properly. Both macroeconomic and bank specific factors should be analysed properly to know their strength and direction of impact on the bad assets. This knowledge can help the bank management, regulators and Government to implement effective NPA resolution plans.

Only domestic banks (see appendix 1) are taken for the study, as management and regulation in the operation of foreign banks are mainly under the control of foreign authorities. This paper has considered Net NPA as a proxy of non-performing assets as it reflects the actual loss of the financial institution as provisions for uncertain and unpaid debt is already deducted. It presents the true picture of asset quality and real loan loss to the entities after 
defaulted loans. Table-1 (see below) shows the result of unit root test, which reflects that four variables are not stationary at level (Return on Assets, GDP growth rate, Exchange Rate and Export rate. After first difference they become stationary. The secondary data that is taken from RBI website an unbalanced panel. Bank specific variables are taken from Statistical Tables relating to Banks in India and the macroeconomic variables are taken from Handbook of Statistic on Indian Economy and World Bank.

\subsection{Panel Data Regression}

Panel data contains time series observations of a number of individuals. Panel data is more advantageous as compared to the others, as it controls heterogeneity across the cross-sections and give unbiased estimation with more efficiency.

\subsubsection{Fixed Effect Estimation}

Fixed effect estimation is a panel data regression model, in which each cross-section units has its own fixed intercept that are time-invariant. It assumes heterogeneity among the units and coefficients of the independent variables do not vary across crosssection units or over time. Two models are taken; along with all other variables, one includes inflation and other includes export.

Model-1,

$\mathrm{NNPA} i t=\alpha i t+\beta 1 \mathrm{GDP} i t+\beta 2 \mathrm{Unemp} i t+\beta 3 \mathrm{CDR} i t+$ $\beta 4 \mathrm{NIM} i t+\beta 5 \mathrm{FDR} i t+\beta 6 \mathrm{ROA} i t+\beta 7 \mathrm{INF} i t+\beta 8 \mathrm{EXR} i t$ $+\varepsilon i, t$.

Model-2,

$\mathrm{NNPA} i t=\alpha i t+\beta 1 \mathrm{GDP} i t+\beta 2 \mathrm{Unemp} i t+\beta 3 \mathrm{CDR} i t+$ $\beta 4 \mathrm{NIMit}+\beta 5 \mathrm{FDR} i t+\beta 6 \mathrm{ROA} i t+\beta 7 \mathrm{EXP} i t+$ $\beta 8 \mathrm{EXR} i t+\varepsilon i, t$.

Where,

Yi,t is NNPAit for $\mathrm{i}$-th bank $(\mathrm{i}=1,2, \ldots .30)$ and $(\mathrm{t}=1,2, \ldots .17)$

$\alpha=$ intercept and $\beta=$ slope coefficient

$\varepsilon i, t=$ error tem

\section{RESULTS AND DISCUSSION}

Table-2 shows the summary statistics of independent variables. Inflation has the minimum value (-3.7) as it was negative in 2016 and maximum (9.6) in 2011.Average growth rate of GDP growth is 7.28 with 1.72 standard deviation. Return on Assets of banks has negative minimum value (-5.39). Export rate and Credit deposit ratio have maintained good average value that is 54.19 and 72.76 respectively.

Table-3 shows the result of regression analysis using fixed effect estimation. The unbalanced panel data suffer from heteroskedasticity and serial correlation with in each panel. To capture these problems banks are clustered in each model. Pearson correlation shows higher collinearity between inflation and export, so two models are considered taking both interchangeably. The Credit deposit ratio is statistically significant at five percent in model-1 and at one percent in model-2, reflects strong negative impact on bad assets as expected earlier. This finding is supported by some earlier literatures such as Swamy (2012); Kaur and Kumar (2018); Mohanty, Das and Kumar (2019) and Ramesh (2019). Better credit management could help the banks to balance their assets quality. Spread (NIM) and Profitability(ROA) have shown negative and significant impact reflecting that with higher profit and interest margins banks can control its bad assets and maintain its assets quality as shown in earlier studies.

Inflation has negative and significant impact on NPA ratio which is consistent to the findings of Kanayake and Azeez (2015); Rajha (2016); Kaur and Kumar (2018); Mazreku et al. (2018) and Szarowskav (2018) but Thomas and Thankur (2021) showed past inflation (WPI) positively affect the bad loans. Growth in export sector has positive spill over effect on entire economy. Even in banking sector, rising export help to reduce or control bad assets. The Export to GDP ratio has strong negative impact on NNPA ratio (Ahmad and Bashir, 2013)

Most important macroeconomic variable; GDP growth has strong negative impact on impaired loans. Fiscal Deficit Ratio has adverse impact on NNPA which is opposed to the result of Patra and Padhi (2016) and Mohanty, Das and Kumar (2019). Exchange rate against US dollar has positive and significant impact on NNPA ratio (Prasanna Thenmozhi, Rana., 2014 and Klein, 2013; Thomas and Thakur, 2021) means increase in exchange rate can raise the non performing assets in banking sector. An appreciation of the exchange rate vis-à-vis the dollar, has two opposite effects: imports are more expensive (supply effects), while exports are less competitive (demand effects). In India the first effect is dominating as the Indian economy is imports driven (Prasanna, Thenmozhi, Rana., 2014). Expensive import reduces the disposable income and savings of individuals. On the other hand, it weakens the debt-servicing capacities of import goods based firms. Hence their repayment capacity adversely gets affected which end up with huge non performing advances. But Kaur and Kumar (2018) had shown negative impact of Exchange Rate on NPAs, as appreciation of domestic currency may weaken the debt-servicing capacities of the export oriented firms and industries.

\section{CONCLUSION}

Three bank specific and six macroeconomic indicators are taken for the panel data regression to study the impact of these factors on the variability in Non Performing assets for Public sector and Private sector bank working in India. Unbalanced panel data is taken from 2004 to 2020. For panel data regression, fixed effect estimation is used with robust standard error. The result found that most of the variables are statistically significant and affirm their expected sign. 
Policy makers and regulators should require banks to be financially sound by maintaining adequate profitability and interest margin as empirical findings suggest these factors having strong impact on NPAs. Credit deposit ratio also helps the bank to reduce loan defaults. Economic growth creates favourable environment for businesses and households by raising their income and savings which enable them to repay their old debt. This finding is supported by most of the earlier studies. The negative association between FDR and NNPA reflects that higher fiscal deficit ratio is a blessing for the economy when government expenditure is towards more productive uses that generate more revenue and employment in the economy. This ultimately raises the repayment and helps the borrowers to meet their debt obligation.

Recently, mergers and acquisition have emerged as a solution for the management of bad assets in the banking system. To faster the resolution of NonPerforming Assets, Srivastava and Chauhan (2018) suggested Artificial Intelligence and big data analysis as a solution as it manage all stages of loan delivery mechanism and control many institutional factors that affect the bad assets in the bank. These areas can be taken for future studies after collecting relevant data related to these areas.

\section{TABLES}

Table-1: Unit root test result of both bank specific and macroeconomic variables

\begin{tabular}{|c|c|c|c|c|}
\hline Variables & & definition & Statistics & Probability \\
\hline NNPA ratio & level & $\begin{array}{l}\text { Net Non-Performing } \\
\text { Assets }\end{array}$ & 120.677 & 0.000 \\
\hline $\begin{array}{l}\text { Unemployment } \\
\text { Rate (Unemp) }\end{array}$ & level & $\%$ of total labour force & 115.422 & 0.000 \\
\hline Inflation(INF) & level & WPI & 77.532 & 0.0635 \\
\hline ROA & $\begin{array}{l}\text { First } \\
\text { difference }\end{array}$ & Return on Assets & 614.305 & 0.000 \\
\hline CDR & level & Credit Deposit Ratio & 196.847 & 0.0000 \\
\hline FDR & level & Fiscal Deficit Ratio & 110.574 & 0.0001 \\
\hline NIM & level & Net Interest Margin & 113.262 & 0.000 \\
\hline Export rate & $\begin{array}{l}\text { First } \\
\text { Difference }\end{array}$ & Export to GDP ratio & 306.569 & 0.000 \\
\hline Exchange rate & $\begin{array}{l}\text { First } \\
\text { Difference }\end{array}$ & $\begin{array}{l}\text { Exchange rate of } \\
\text { Rupees against US } \\
\text { dollar }\end{array}$ & 416.877 & 0.000 \\
\hline GGDP & $\begin{array}{l}\text { First } \\
\text { Difference }\end{array}$ & $\begin{array}{l}\text { Annual Growth rate of } \\
\text { Gross domestic } \\
\text { Product }\end{array}$ & 248.146 & 0.000 \\
\hline
\end{tabular}

Source: Author's Computation.

Table-2: Descriptive summary of both bank specific and macroeconomic variables.

\begin{tabular}{llllll}
\hline Variables & Obs & Mean & St.Dev & Min & Max \\
\hline Unemp & 510 & 5.62 & 0.39 & 5.27 & 7.11 \\
INF & 510 & 4.61 & 3.16 & -3.7 & 9.6 \\
GGDP & 510 & 7.28 & 1.72 & 4.1 & 9.7 \\
EXP & 510 & 13.78 & 2.01 & 10.91 & 17.16 \\
EXR & 510 & 54.19 & 10.2 & 40.26 & 70.89 \\
FDR & 510 & 4.35 & 1.04 & 2.5 & 6.6 \\
ROA & 509 & 0.79 & 0.94 & -5.39 & 2.43 \\
NIM & 509 & 2.84 & 0.693 & 1.07 & 5.61 \\
CDR & 509 & 72.76 & 12.04 & 40.79 & 162.71 \\
\hline
\end{tabular}

Source: Author's Computation. 
Table-3: Result of empirical analysis of two model s in STATA16.

\begin{tabular}{lll}
\hline Dependent var-Net NPA & Model-1 & Model-2 \\
\hline Unemployment & -0.3078 & -0.0063 \\
& $(0.2197)$ & $(0.2038)$ \\
Inflation & $-0.3271^{* * *}$ & \\
GDP growth & $(0.0494)$ & $-0.3258 * * *$ \\
& $-0.4074 * * *$ & $(0.0532)$ \\
Exchange rate & $(0.0574)$ & $0.0734 * *$ \\
& 0.0028 & $(0.0177)$ \\
Fiscal Deficit rate & $(0.0135)$ & $-0.6782^{* * *}$ \\
Net Interest Margin & $-0.2821^{* * *}$ & $(0.0955)$ \\
Return on Assets & $(0.0646)$ & $-1.1622^{* * *}$ \\
& $-1.1034 * * *$ & $(0.3436)$ \\
Credit Deposit Ratio & $(0.3226)$ & $-0.7840^{* * *}$ \\
Export Rate & $-0.7086^{* * *}$ & $(0.1308)$ \\
& $(0.1351)$ & $-0.0425 * * *$ \\
\hline
\end{tabular}

Source: Author's computation

$* * *$ indicates that the variable is statistically significant at $1 \%$ and $* *$ reflects significance level at $5 \%$.

Robust Standard error is in parenthesis.

\section{REFERENCES}

1. Ahmad, F., \& Bashir, T. (2013), "Explanatory Power of Macroeconomic Variables as Determinants of Non- Performing Loans: Evidence from Pakistan," World Applied Science Journal, 22(2), p.p: 243-255. https://doi.org/10.5829/idosi.wasj.2013.22.02.18 63

2. Bardhan,S., Sharma,R. \& Mukherjee, V. (2019), "Threshold Effect of Bank-specific Determinants of Non-performing Assets: An Application in Indian Banking," Journal of Emerging Market Finance, 18(1S), p.p: $1 S-34 S$.

3. Bhattarai, B. P., (2018), “Assessing Banks Internal and Macroeconomic factors as Determinants of Non-Performing Loans : Evidence from Nepalese Commercial Banks,"

4. International Journal of Accounting and Finance Review,3(1),p.p:13-3.

5. Dhar, S., \& Bakshi, A. (2015), "Determinants of loan losses of Indian Banks : a panel study,"

6. Journal of Asian Business Studies, August, 9(1), p.p:17-32. https://doi.org/10.1108/JABS-

7. 0420120017

8. Ghosh, A. (2015), "Banking-industry specific and regional economic determinants of NonPerforming Loans: Evidence from US States," Journal of Financial Stability,p.p:1-36, https://doi.org/10.1016/j.jfs.2015.08.004

9. Kadanda, D., \& Raj, K. (2018), "Non-performing assets (NPAs) and its determinants : a study of Indian public sector banks," Journal of Social and Economic Development, 20(2), p.p:193-212, https://doi.org/10.1007/s40847-018-0068-0

10. Kaur, M\& Kumar, R. (2018), “Bank Specific and Macro Determinants Influencing Non Performing Assets in Indian Public Sector Banks," Pacific Business Review International, 10 (7), p.p: 125-132.

11. Ekanayake, E.M.N.N \& Azeez, A.A (2015),
"Determainants of NON- PERFORMING LOANS IN LICENSED COMMERCIAL BANKS:EVIDENCE FROM SRI LANKA," Asian Economic and Financial Review, 5(6),p.p: 868882.

12. Klein, N. (2013), "Non-Performing Loans in CESEE: Determinants and Impact on Macroeconomic Performance," IMF Working Paper, European Department, WP/13/72.

13. Kumar et al. (2018), "Determinants of nonperforming loans in banking sector in small developing island states: a study of Fiji," Accounting Research Journal, https://doi.org/10.1108/ARJ-06-2015-0077

14. Киzиси, N. \& Kuzиси, S. (2019), "What Drives Non-Performing Loans? Evidence from Emerging and Advanced Economies during Preand Post-Global Financial Crisis," Emerging Markets Finance and Trade, p.p: 1-15, DOI: 10.1080/1540496X.2018.1547877

15. Mazreku et al. (2018), "Determinants of the Level of Non-Performing Loans in Commercial Banks of Transition Countries," European Research Studies Journal, XXI (3),p.p: 3-13.

16. Mohanty, A.R., Das, B.R. \& Kumar, S., (2019), "Determinants of Non-Performing Loans in India: A System GMM Panel Approach," Prajnan, XLVII (1), p.p: 37-55.

17. Patra, B. \& Padhi, P (2016), "Determinants of nonperforming assets-bank-specific and macroeconomic factors: A panel data analysis of different group of commercial banks operating in India," Theoretical and Applied Economics, XXIII (4), winter, p.p:215-236.

18. Prasanna, P. K., Thenmozhi, M., \& Rana, N. (2014), " Determinants of non-performing advances in Indian banking system," Banks and Bank Systems, 9(2), p.p: 65-77.

19. Rajha, K. S. (2016), "Determinants of NonPerforming Loans : Evidence from the Jordanian 
Banking Sector,” 4(1), p.p:125-136, https://doi.org/10.15640/jfbm.v4n1a9

20. Ramesh, K. (2019), "Bad Loans of Public Sector Banks in India : A Panel Data Study," Emerging Economy Studies, p.p:1-9, https://doi.org/10.1177/2394901519825911

21. Reddy, S. (2015), "Non-Performing Loans in Emerging Economies - Case Study of India," Asian Journal of Finance and Accounting, 7(1),p.p: 183-206.

22. Roy, S. G. (2014), "DETERMINANTS OF NONPERFORMING ASSETS IN INDIA-PANEL REGRESSION," Eurasian journal of economics and finance. 2(3), p.p:69-78. https://doi.org/10.15604/ejef.2014.02.03.005

23. Sopan, J. \& Dutta, A.(2018), "Determinants of Liquidity Risk in Indian Banks:A Panel Data Analysis, " Asian Journal of Research in Banking and Finance, 8(6), p.p: 47-59.

24. Srivastava, $S \&$ Chauhan, $P$. (2018), "Institutional Factors influencing NonPerforming Assets (NPA) in Indian Banking Sector and use of Artificial Intelligence as a remedial tool," Indore Management Journal,10(1),p.p:46-56.
25. Swamy, V. (2013), “ Impact of Macroeconomic and Endogenous Factors on Non-Performing Bank Assets," The International Journal of Banking and Finance,9(1),p.p: 27-47.

26. Szarowska, I. (2018), "Effect of macroeconomic determinants on non-performing loans in Central and Eastern European countries," International Journal of Monetary Economics and Finance, 11(1), p.p: 20-34.

27. Thomas, R. \& Thakur, R. R. (2021), "Are Increased Profits Always a Sign of Better Management? Evidence from Indian Banks using Dynamic Panel Data Approach," UNNAYAN, XIII (I), p.p:102-121.

28. Waqas et al. (2017), "Determinants of Nonperforming Loans: A Comparative Study of Pakistan, India, and Bangladesh," Journal of Finance \& Banking Studies, 6(1), p.p: 51-68, https://doi.org/10.20525/ijfbs.v6il.617

29. Zheng, C., Bhowmik, P. K., \& Sarker, N. (2020), "Industry-Specific and Macroeconomic Determinants of Non-Performing Loans: A Comparative Analysis of ARDL and VECM," Sustainability, 12(325), p.p:1-17

Appendix-1: Names of the selected banks.

Public Sector Banks

Private Sector Banks

$\begin{array}{ll}\text { Allahabad Bank } & \text { Indian Bank } \\ \text { Andhra Bank } & \text { Oriented Bank of Commerce } \\ \text { Bank of Baroda } & \text { Punjab National Bank } \\ \text { Bank of India } & \text { State Bank of India } \\ \text { Canara Bank } & \text { Syndicate Bank } \\ \text { Central Bank of India } & \text { UCO Bank } \\ \text { Corporation Bank } & \text { Union Bank of India } \\ \text { Indian Overseas Bank } & \end{array}$

Indian Overseas Bank

\author{
Karnataka Bank \\ Kotak Mahindra Bank \\ Karur Vysya Bank \\ RBL Bank \\ South Indian Bank \\ Tamilnad Mercantile Bank \\ YES Bank
}

Source: RBI website 